\title{
The Role of Reputation for Achieving Competitive Advantage
}

\author{
Sri Sarjana ${ }^{1 *}$ and Nur Khayati ${ }^{2}$ \\ ${ }^{1}$ Faculty of Economics and Business, Padjajaran University \\ Email: srisarjana@gmail.com \\ ${ }^{2}$ SMAN 1 Cikarang Utara, Bekasi
}

\begin{abstract}
Corporate reputation is an assessment of stakeholders based on their existence, leadership, and innovation. This study empirically investigates the effects of corporate social responsibility (CSR), dynamic capabilities, reputation, and competitive advantage in manufacturing industries. An active role of manufacturing industries for involvement in CSR is needed by stakeholders in order to sustain the economic, social, and environmental aspects that ultimately increase the reputation of an objective that can be achieved by manufacturing industries. The development of dynamic capabilities is an internal factor for manufacturing industries into sections to win a competitive advantage. The authors conducted a survey to test the hypotheses and designed a SEM to analyze them. The results show that CSR has a positive effect on reputation. Dynamic capabilities have an effect on competitive advantage. This study concludes that reputation has an effect on competitive advantage. This finding integrates insights in a reputation framework into a generalization having a direct effect on competitive advantage in manufacturing industries. This research is expected to provide manufacturing industries with valuable suggestions for management practices to increase reputation and achieve the industrial goals especially to win the competitive advantage.
\end{abstract}

Keywords: competitive advantage, reputation, CSR, dynamic capability

\section{Introduction}

Opportunities and benefits for firms, such as cost reductions, efficiency improvements, better supplier relationships, access to global markets, new customers and suppliers, productivity improvements, increased profits and gains in competitive advantage (Fauska et al., 2013). Increasingly corporations are engaging generous financial resources to develop image of doing good to strengthen its relationships with all stakeholders particularly customers, employees, investors, the government, and the community (Ali, 2011). Internal firm capabilities and resources have not been dynamic enough in the past to warrant the use of transient that might also change in the new business environment (Wang, 2014). The high competition on business in the manufacturing industry has experienced significant improvement. There are several manufacturing businesses in an industrial area in Bekasi and Karawang unable to compete and having recently suffered setback, and even a few went bankrupt. Thus, it is necessary to increase the performance in dealing with situations and conditions that change fast, erraticly, and unpredictably, and it is important for the manufacturing industries to maintain their positive reputation. Therefore, compliance and strengthening capabilities in the manufacturing industries 
become an important issue to improve reputation and to win in competitive advantage besides involving CSR. Assessment reputation for the company by the government, especially by the Ministry of Environment, in encouraging the arrangement of companies in environmental management is done through the program performance rating (PROPER) based on the five categories: gold, green, blue, red, and black. The aim of this study is to increase company reputation through CSR and dynamic capabilities in order to win the competitive advantage in an industrial area. Reputation creates stakeholders' perspective that is needed to sustain the existence of business.

\section{Literature Review}

\subsection{Corporate Reputation}

Reputation is defined as the total set of individuals and collective judgments on the reliability of an institution based on a general set of values, their trustworthiness, and competence (Golgeli, 2014). Corporate reputation is defined as subjective and collective recognition, perception, attitude and evaluation of an organization over time between all involved stakeholder groups based on specific organizational quality aspects, past behavior, communication, symbolism, possibility, and potential to satisfy future expectations compared to competitors (SontaitePetkeviciene, 2014). Corporate reputation reflects people's perception about the company (Sandu, 2015). A company's reputation is the perceptions of its relevant stakeholders, such as customers, employees, owners, suppliers and strategic partners, society and community, governmental or non-governmental organizations, among others (Martínez \& del-Bosque, 2014). Corporate reputation is a latent assessment construct driven by both individualistic and collectivist organizational identities built on trust (Agarwal et al., 2015).

Good reputation is a valuable asset that allows a firm to achieve persistent profitability or sustained and superior performance (Baldarelli \& Gigli, 2014). Measurement of corporate reputation includes customers' excellent comprehensive sense of total experience in the corporate, customers being optimistic about the long-term future of the corporate, the corporate being characterized with honesty, credibility, and dependability (El-Garaihy et al., 2014). The dimensions of corporate reputation, such as good products or services, vision and leadership, good workplace environment, social \& environmental responsibility, financial performance, emotional appeal (Agarwal et al., 2015). The dimensions of reputation include financial performance, quality of management, business strategy, structure of organization, quality of leadership, human resources, organizational culture, ethics, corporate social responsibility, product offer, brand image, innovation and value creation, global reach (Olmedo-Cifuentes et al., 2014). Corporate reputation is the assessment and perception by stakeholders based on the quality of products and services, quality of leadership, financial performance, human resources, and innovation.

\subsection{Competitive Advantage}

Competitive advantage is broadly covered in the literature in terms of cost reductions, differentiation, growth, and quality (Elbeltagi et al., 2016). Competitive advantage means that the firm can produce goods or services that their customers find more valuable than the goods or services produced by their competitors (Saloner et al., 2001). Roger (2010) describes the sources of the competitive advantage, such as cost advantage, differentiation of advantage and 
marketing advantage. Quality as one of the components of a competitive advantage can be achieved in different areas of the organization, such as product and service quality, information quality, quality of relations with business partners (N'Da et al., 2008). Competitive advantage is the one that characterizes and makes something better than all its competitors (Sakas et al., 2014).

The dimension of competitive advantage includes cost, quality, and delivery (Chamsuk et al., 2015). Competitive advantages can be created through innovation, efficiency, quality, and customer responsiveness (Attiany, 2014). Knowledge can be considered as a competitive advantage since organizations can hardly imitate its competitors (Kaveh et al., 2015). The way for current business environment has evolved, and opportunities for leveraging competitive advantage are transient (Wang, 2014). Competitive advantage is company's strategy to create the value of products or services that have uniqueness, differentiation, and cost leadership very beneficial for customers if compared to those belonging to competitors.

\subsection{Corporate Social Responsibility (CSR)}

CSR is a process with the aim to embrace responsibility for the company's actions and to encourage a positive impact through its activities on the environment, consumers, employees, communities, stakeholders, and all other members of the public that may also be considered stakeholders (Gaurangkumar, 2015). CSR is a company's sense of responsibility towards the community \& environment where it operates ecologically \& socially. CSR is a continued promise by companies to act ethically, to contribute to sustainable economic development, and to contribute to improvement of quality of life of its employees, their families, as well as local communities and society as a whole (Cierna \& Sujova, 2015). CSR refers to companies taking responsibility for their impact on society, reflected by the intention, actions, and performance of specific enterprises to strive to maximize social welfare during the term of their existence under specific institutional arrangements (Hongjun, 2014).

CSR has emerged as an effective way for firms to create favorable attitudes among consumers (Mark et al., 2011). CSR strategy processes include the requirement for informative communications rather than persuasive negotiations and the absence of resistance within the organizational community (Sharp \& Zaidman, 2010). CSR activities make the corporation more attractive for a variety of stakeholders, such as employees, business partners, shareholders, governments and customers, increase its brand loyalty, image and awareness, long-term commitment, environmental protection, and reduce the loss of corporate reputation (Erkmen \& Esen, 2014). The CSR approach is holistic and integrated with the core business strategy for addressing social and environmental impacts of businesses (Kaur, 2015). CSR is the commitment of a company as a consequence of the impact of its activity on the environment through efforts in the economic, environmental, and social fields, community, and ethics to improve the welfare and interests of sustainability for the company and its stakeholders.

\subsection{Dynamic Capabilities}

Dynamic capabilities as a process are related to organization's ability to reconfigure the basis of its resources in order to respond to more efficient changes in a field of its activity (Masteika \& Cepinskis, 2015). Dynamic capabilities are the ability of a firm to deploy new configurations of operational competencies relative to the competition by effectively sensing the environment, 
as well as being absorptive, integrating, having innovative activities (Hou, 2008). Dynamic capabilities are defined as an ability to create and reconfigure the resources to adapt rapidly changing markets (Wang \& Ahmed, 2007). Dynamic capabilities represent the ability of a firm to create new manufacturing processes, new products, and services in order to rapidly respond to changing environments (Helfat et al., 2007). Dynamic capabilities refer to a firm's ability to integrate, establish, and redeploy internal and external resources into the best configuration in order to be able to create and develop new capabilities and create new market opportunities (Eisenhardt \& Martin, 2000).

Pavlou \& El Sawy (2011) explain the dimension of dynamic capabilities, such as sensing, learning, integrating, and coordinating capabilities, as a sequential logic to reconfigure existing operational capabilities. Dynamic capabilities emphasize the transforming of environmental characteristics and how firms manage to adapt, integrate, and reconfigure the internal and external organizational resources to compete with the dynamic environmental conditions (Teece, 2007). Some capabilities act as both dynamic and operational capabilities and are used to renew operational capabilities to simultaneously maintain a firm's current operations and to positively influence overall firm performance (Helfat \& Winter, 2011). Firms should renew their resource base upon the dynamic capability approach which deploys relevant capabilities, as dynamic capabilities hold the potential for a sustained competitive advantage especially in a turbulent environment (Breznik \& Lahovnik, 2016). Dynamic capabilities are the ability and competence of a company to utilize its resources through the process of scanning, sensing, learning, integration, and coordination in the face of the rapid global environmental change in order to create a competitive advantage.

\section{Theoretical Framework and Hypotheses}

Information infrastructure capability has the potential to increase organizational competitive advantage (Ling et al., 2014). The concept of CSR has grown exponentially in importance and significance (Gazzola, 2014). Zheng et al. (2011) explain that a firm can continually renew their knowledge base through its dynamic capabilities so that it is possible to respond to changing environments. Wang \& Ahmed (2007) explain that dynamic capabilities help enhance corporate performance, particularly when an enterprise has a synchronized development capacity and corporate strategy, which can lead to superior performance. The primary premise of the dynamic capability framework is that a firm has operational capabilities and resources (Teece et al., 1997). Firms with a stronger commitment to deploy dynamic capabilities are more successful and hold the potential for a sustained competitive advantage (Breznik \& Lahovnik, 2014). Dynamic capabilities focus on modifying the firm resources to match with the changing environment (Bowman \& Ambrosini, 2003).

There is a significant association between CSR and corporate reputation (Gazzola, 2014). Dynamic capabilities are a closing influence on competitive advantages and have implications to performance (Marichova, 2014). This research model is developed, and the modification from previous research is included (Gazzola, 2014 and Marichova, 2014). CSR, dynamic capabilities, reputation, and competitive advantage are used to comprehend relationships between variables at manufacturing industries. This study attempts to merge and combine multiple variables from previous studies for the development of the model. The research model is an attempt to assist the management in manufacturing industries to consider several variables that can affect business performance. 


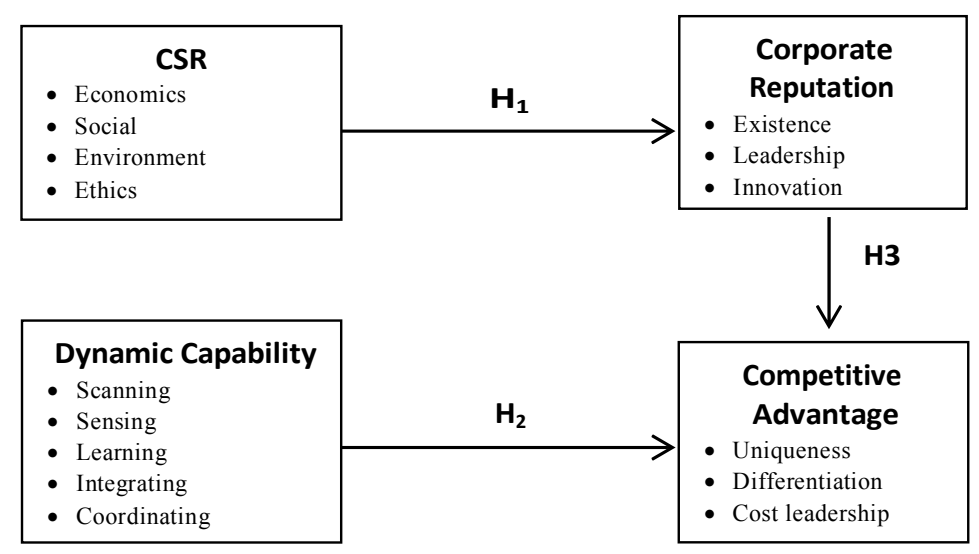

Figure 1. Research paradigm

Hence, based on the previous literature review we propose three hypotheses formulated as follows:

$\mathrm{H}_{1}$ : CSR has a positive direct effect on reputation.

$\mathrm{H}_{2}$ : Dynamic capabilities have a positive direct effect on competitive strategy.

$\mathrm{H}_{3}$ : $\quad$ Reputation has a positive direct effect on competitive advantage.

\section{Methodology}

The main objective of this research is to investigate the influence of CSR and dynamic capability impact on reputation and implication on competitive advantage at manufacturing industries. The unit of observation is the manufacturing managers in Bekasi and Karawang, especially in industrial areas. The main design of this study is to test the theory verification or results of previous studies. This study aims to implement corporate reputation as a sampling frame. A great deal of research has been conducted in various industries such as manufacturing (Kylaheiko \& Sandstrom, 2007). The data analysis for the research was conducted by the researchers using the Lisrel 8.8 to assist in the analysis of the variables and the application of the structural equation modeling analysis of the causal relationship between variables. Hair et al. (2010) state that the size of the sample has to be large enough to be used in the data analysis by the application of the model equations with the structure and the distribution of data.

Data were collected from 206 industries engaged in an industrial area. The industrial areas located in Bekasi consist of MM2100, Jababeka, EJIP, Hyundai, Delta Silikon. The industrial areas located in Karawang include KIIC, Surya Cipta, Kota Bukit Indah. The sampling method used stratified random sampling. Subsequently, simple random sampling was applied for each stratified random sample to the data collected from the surveyed population. Population consists of manufacturing industries in Indonesia especially those located in Karawang and Bekasi. The data were collected from manufacturing industries to distribute through email and face to face conversations. Of the total target sample questionnaires, 300 questionnaires were distributed, and 94 were discarded as incomplete. Hence, the final response rate was 68.7 percent. Data were gathered from January to March 2016. The operational variables show dimensions and indicators used to measure the research variables. Measurements used a Likert scale with 5 points to obtain a clear view of the respondents. This study classifies four variables, such as 
Table 1 Demographic Respondents

\begin{tabular}{llcc}
\hline Demographics profile & Category & No. of respondent & $\%$ \\
\hline \multirow{2}{*}{ Years of existence } & Less than 5 years & 94 & 45.6 \\
& $5-10$ years & 74 & 35.9 \\
No. of employees & Over 10 years & 38 & 18.5 \\
& Fewer than 10 & 3 & 1.4 \\
& $11-100$ & 84 & 40.8 \\
Background activities & $101-1000$ & 98 & 47.6 \\
& Over 1000 & 21 & 10.2 \\
& Automotive & 87 & 42.2 \\
& Electronics & 58 & 28.2 \\
& Food \& Beverages & 34 & 16.5 \\
& Logistics & 25 & 12.1 \\
& Others & 2 & 1 \\
\hline
\end{tabular}

CSR, dynamic capability, corporate reputation, and competitive advantage. The statistical results obtained from the questionnaires were analyzed.

The next step in this research is to examine the validity and reliability. Test validity demonstrates the extent to which the precision and accuracy of the instrument can measure a construct. The test of validity is measured with the confirmatory factor analysis. Moreover, the reliability test is used to measure the internal consistency of the construct indicator that shows the degree of each indicator that indicates a common construct. Test reliability is measured by calculating the construct reliability and variance extracted. Finally, we decided to conduct our research more specifically on the manufacturing industries for several reasons. First, it is a sector in which industries' responsible initiatives are developed and improved. Second, this research field helps us avoid the limitation of industries' experiments since data were obtained in a real condition of use. The analyzed problems were solved with the use of mainly quantitative research methods.

\section{Analysis and Results}

Table 1 shows that for the profile of respondents the results reveal that $45.6 \%$ of the respondents have less than 5 years of existence and $18.5 \%$ of the respondents have worked over 10 years. With regard to the number of employees, $47.6 \%$ have the biggest number of employees with around 101-1000 employees, and most of them have around 42.2\% respondents with the background activities of automotive industries as they experience the most effect in this survey.

Testing the validity of this research refers to the loading factor values obtained from standardized regression weight compared with a cut of value. The instrument is said to be valid if the value of the loading factor is $\geq 0.5$. Reliability testing was done by calculating the value of the construct reliability and variance extracted. An instrument is said to have a good level of reliability when construct reliability value is $\geq 0.70$ and variance extracted values are $\geq 0.5$. Table 2 shows construct reliability and a variance extracted test.

Based on the calculations of construct reliability and variance extracted, every indicator known to all indicators was declared valid because it has a factor loading $\geq 0.5$ or has a loading factor greater than two times the standard error. As the value of construct reliability is $\geq 0.70$ and the value of variance extracted is $\geq 0.5$, it can be concluded that all of the constructs and indicators used in this study have the value of good validity and reliability. The indicators of each construct were adopted from various previous studies that can be implemented properly in this study. 
Table 2 Construct reliability and variance extracted test

\begin{tabular}{llrrrrrr}
\hline \multirow{2}{*}{ Variable } & Indicator & $\lambda$ & $\lambda^{2}$ & $\mathrm{e}$ & $\mathrm{CR}$ & $\mathrm{VE}$ & Interpretation \\
\hline \multirow{2}{*}{ CSR } & Economics & 0.940 & 0.884 & 0.116 & 0.95 & 0.83 & valid \& reliable \\
& Social & 0.880 & 0.774 & 0.226 & & & \\
& Environmental & 0.870 & 0.757 & 0.243 & & & \\
Dynamic & Ethics & 0.960 & 0.922 & 0.078 & & & \\
Capability & Scanning & 0.890 & 0.792 & 0.208 & 0.96 & 0.84 & valid \& reliable \\
& Sensing & 0.890 & 0.792 & 0.208 & & & \\
& Learning & 0.960 & 0.922 & 0.078 & & & \\
& Integrating & 0.960 & 0.922 & 0.078 & & & \\
Corporate & Coordinating & 0.880 & 0.774 & 0.226 & & & \\
Reputation & Existence & 0.785 & 0.616 & 0.383 & 0.77 & 0.54 & valid \& reliable \\
& Leadership & 0.807 & 0.651 & 0.348 & & & \\
Competitive & Innovation & 0.586 & 0.343 & 0.657 & & & \\
Advantage & Uniqueness & 0.970 & 0.941 & 0.059 & 0.99 & 0.96 & valid \& reliable \\
& Differentiation & 0.100 & 0.100 & 0.000 & & & \\
& Cost leadership & 0.970 & 0.941 & 0.059 & & & \\
\hline
\end{tabular}

The analysis model shows that the research model fits the data. Furthermore, the hypothesis tested indicates an analysis of the influence of the CSR, dynamic capability, reputation and competitive advantage. Figure 2 shows the standardized coefficients for the structural relations tested. As can be seen from the figure, the goodness of fit indices for the structural model shows a good fit; therefore, it is feasible to test the proposed hypotheses. H1 is supported $(\beta 1=0.61)$ as the CSR dimension in industries on reputation. That means $\mathrm{H} 1$ describes that CSR has a positive direct effect on reputation. $\mathrm{H} 2$ and $\mathrm{H} 3$ are confirmed $(\beta 2=-0.50 ; \beta 3=1.13)$ as CSR and dynamic capabilities. This is understood that dynamic capabilities have a positive direct effect on competitive advantage. These results give empirical support to the idea that the efforts made by industries will be rewarded by the projection of a positive reputation that will lead to increasing competitive advantage. Finally, $\mathrm{H} 4$ expects that reputation will have a positive direct effect on competitive advantage $(\beta=0.39)$, and it is supported. Therefore, the proposed model is totally supported by the results.

The model indicates a confirmatory factor analysis procedure to access all constructs involved in the study. The data are the score of 206 managers in industries on construct activities. The structural model result in Table 3 shows the achieved stable model fit estimation. The indicators of fit: $\mathrm{Cmin} / \mathrm{df}=4.170(\mathrm{Cmin}=345.58, \mathrm{df}=85) ; \mathrm{GFI}=0.82 ; \mathrm{RMR}=0.38 ; \mathrm{NFI}=0.82 ; \mathrm{CFI}$ $=0.86$; RMSEA $=0.122$. The SEM result empirically shows that reputation has a highly significant influence $(\beta=0.39, \mathrm{p}=.0000)$ on competitive advantage. These indices suggest that the structural model provides a good fit to the data at hand and has yielded a corroborating value for the good model fit.

Table 3. SEM Result

\begin{tabular}{llll}
\hline Hypotheses & \multicolumn{1}{c}{ Structural Relationship } & $\begin{array}{c}\text { Standard Coefficient } \\
\text { (Robust t-value) }\end{array}$ & Contrast \\
\hline $\mathrm{H}_{1}$ & CSR $\rightarrow$ reputation & $0.61(4.86)$ & Accepted \\
$\mathrm{H}_{2}$ & Dynamic capabilities $\rightarrow$ competitive advantage & $1.13(2.21)$ & Accepted \\
$\mathrm{H}_{3}$ & Reputation $\rightarrow$ competitive advantage & $0.39(2.74)$ & Accepted \\
& $\mathrm{NFI}=0.82 \mathrm{NNFI}=0.83 \mathrm{CFI}=0.86$ & $\mathrm{IFI}=0.86$ & \\
& $\chi^{2}=345.58, \mathrm{df}=85, p=0.000$ & RMSEA $=0.122$ & \\
\hline Significant at $p<0.05$ & &
\end{tabular}




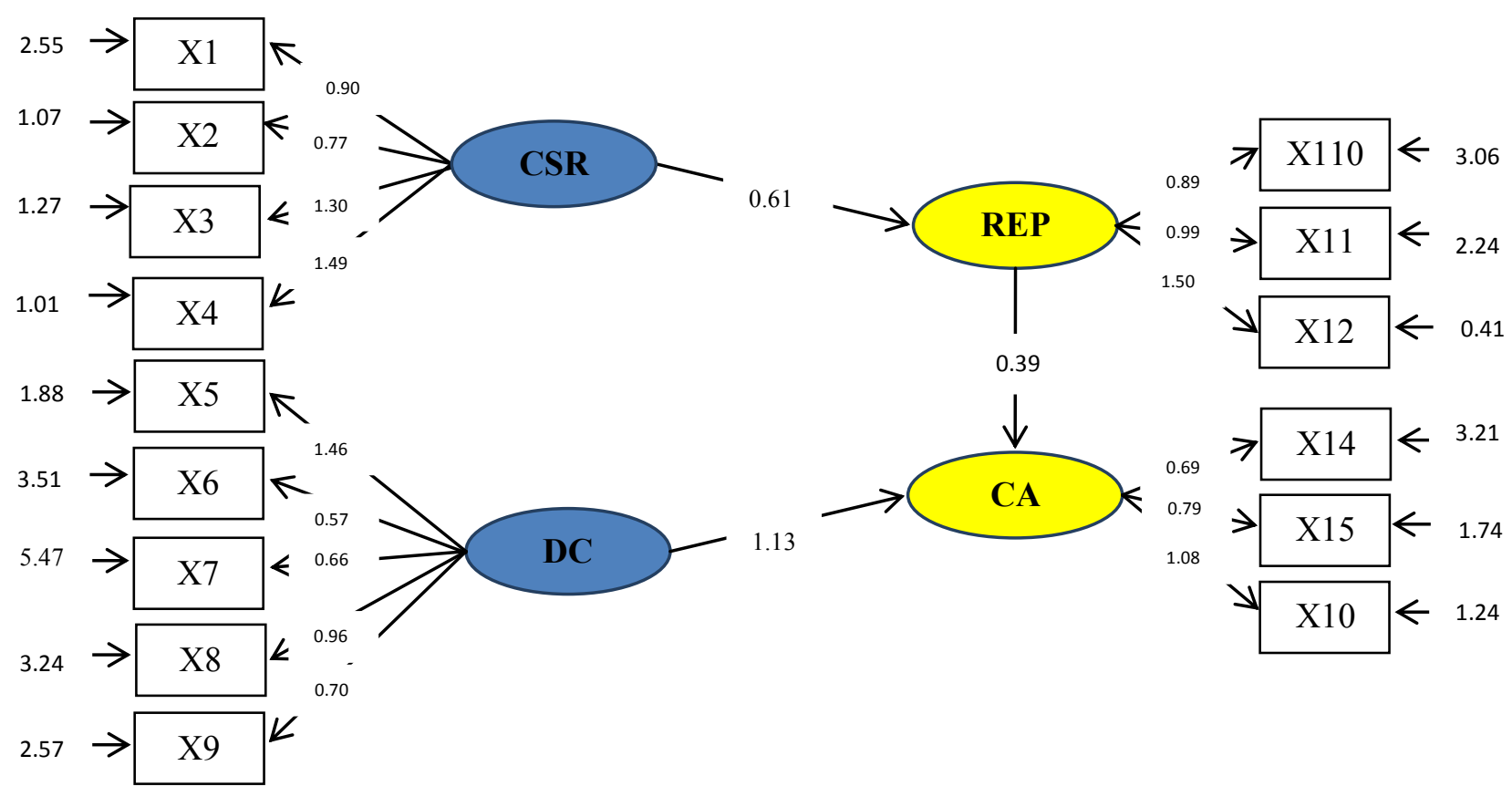

Figure 2. Structural model estimation

\section{Discussion and Conclusion}

This study empirically investigates whether there is an effect of CSR, dynamic capabilities, reputation, and competitive advantage in industrial areas in Bekasi and Karawang, Indonesia. The authors conducted a survey to examine the hypotheses and designed a SEM to analyze them. The results show that CSR has a positive effect on reputation in manufacturing industries. CSR has a significant positive influence on corporate reputation (Ali, 2011). Another result shows that the dynamic capabilities have a direct effect on competitive advantage. Dynamic capabilities increase organizational performance and provide competitive advantages (Tseng \& Lee, 2014). CSR strategy will become more rules based by firms that aim to effectively manipulate and control their capabilities and resources that are valuable, rare, and not easily imitated without a perfect substitute available to generate sustainable competitive advantages (Chung \& Safdar, 2014). The dynamic capabilities are identified and treated as a system of specific, identical firm strategic actions, decisions, and organizations that create higher value compared to competitors, and therefore resulting in sustainable business advantage (Marichova, 2014). Our empirical evidence supports all the proposed hypotheses. Moreover, this study describes that reputation has a positive effect on competitive advantage where CSR is mediated by reputation. Having a good reputation can drive business success in the long-term, and losing reputation creates an obstacle to this success (Gazzola, 2014).

CSR becomes evidence for the manufacturing industries to contribute to the sustainability of businesses, particularly in maintaining the good perception of stakeholders in industrial areas especially in Bekasi and Karawang. The active role of manufacturing industries for involvement in CSR is needed by stakeholders in order to sustain the economic, social, and environmental aspects of businesses that ultimately increase the reputation of an objective that can be achieved by manufacturing industries. In addition, the strengthening of dynamic capabilities as an internal factor becomes important in achieving a competitive advantage in the industrial areas in Bekasi and Karawang. As a result of the circumstances of global rapid 
changing and difficulty to predict, the manufacturing industries should be able to develop the dynamic capabilities to ensure the sustainability of the company to deal with rapid change and be able to compete in the global competition, and thus finally being able to win in the business competition. Manufacturing industry involvement in CSR activities can contribute to strengthening reputation. The development of dynamic capabilities is an internal factor for manufacturing industries into sections that help to win a competitive advantage. Business competition will be won if it has a good reputation. Socially responsible behaviors can increase a company's value in that they increase the degree of confidence of the various stakeholders and the level of reputation (Gazzola, 2014). Dynamic capabilities have a direct influence on competitive advantage. Dynamic capabilities through functional competence of the company build competitive advantage and the realization of business objectives (Marichova, 2014). This should give the industries the idea that they need to justify the policy that is associated with issues regarding sustainable industries. However, industries must become much more interested in the strategic management implications of their sustainable industries' policies and actions, including CSR and dynamic capabilities, since this research demonstrates the effects of these aspects on reputation and competitive advantage.

Finally, to refine the findings of this study, some limitations of this work are outlined below. The present research focuses on the concepts of reputation, competitive advantage, CSR and dynamic capabilities in manufacturing industries. Our findings suggest that CSR and dynamic capability aspects are key components, and that there are richer and in-depth views of the concept between reputation and competitive advantage. Dynamic capabilities are the key significant capabilities for achieving organizational competitive advantage (Ling et al., 2014). Dynamic capabilities influence firm performance indirectly by helping the firm renew its existing operations by updating, recombining, and reconfiguring its existing operational capabilities (Gao \& Tian, 2014). Future research could extend this research by including different stakeholder expectations of CSR, dynamic capabilities, reputation, and competitive advantage. Therefore, it would be interesting to replicate this study, but we have to consider various stakeholders to ensure that our results are extrapolated to use another variable, especially for the study of industries, such as corporate image, governance, leaderships, innovation, performance, satisfaction.

\section{References}

Agarwal, J., Osiyevskyy, O., \& Feldman, P.M. (2015). Corporate Reputation Measurement: Alternative Factor Structures, Nomological Validity, and Organizational Outcomes. Journal Business Ethics, 130, 485-506.

Akman, G., \& Yilmaz, C. (2008). Innovative capability, innovation strategy and market orientation: An empirical analysis in Turkish software industry. International Journal of Innovation Management, 12(1), 69-111.

Ali, I. (2011). Influence of Corporate Social Responsibility on Development of Corporate Reputation and Customer Purchase Intentions. Romanian Review of Social Sciences, 1, 19-27.

Attiany, M.S. (2014). Competitive Advantage through Benchmarking: Field Study of Industrial Companies Listed in Amman Stock Exchange. Journal of Business Studies Quarterly, 5(4), 41-51. 
Baldarelli, M., \& Gigli, S. (2014). Exploring the Drivers of Corporate Reputation Integrated with a Corporate Responsibility Perspective: Some Reflections in Theory and in Praxis. Journal Management Governance, 18, 589-613.

Barney, J.B. (1991). Firm Resources and Sustained Competitive Advantage. Journal of Management, 17(1), 99-120.

Bowman, C. \& Ambrosini, V. (2003). How the Resource-based and the Dynamic Capability Views of the Firm Inform Corporate Level Strategy. British Journal of Management, 14, 289-303.

Breznik, L. \& Lahovnik, M. (2014). Renewing the Resources Base in Line with the Dynamic Capabilities View: A key to Sustained Competitive Advantage in the IT Industry. Journal of East European Management Studies, 19(4), 453-485.

Chamsuk, W., Phimonsathien, T., \& Fongsuwan, W. (2015). Research and Development $(R \& D)$ Capabilities and Innovation Capability that Affect the Enterprise Competitive Advantage in the Thai Automotive Parts Industry: SEM Approach. International Journal of Arts \& Sciences, 08(02), 441-457.

Chung, M., \& Safdar, N. (2014). Firms Strategic CSR Choices during the Institutional Transition in Emerging Economies. International Review of Management and Business Research, 3(3), 1709-1727.

Cierna, H., \& Sujova, E. (2015). Parallels between Corporate Social Responsibility and the EFQM Excellence Model. MM Science Journal, 670-676.

Cruz, L.B., \& Boehe, D.M. (2010). How do Leading Retail MNCs Leverage CSR Globally? Insights from Brazil. Journal of Business Ethics, 91, 243-263.

Elbeltagi, I., Hamad, H., Moizer, J. \& Abou-Shouk, M.A. (2016). Levels of Business to Business E-Commerce Adoption and Competitive Advantage in Small and MediumSized Enterprises: A Comparison Study between Egypt and the United States. Journal of Global Information Technology Management, 19(1), 6-25.

El-Garaihy, W.H., Mobarak, A.M., \& Albahussain, S.A. (2014). Measuring the Impact of Corporate Social Responsibility Practices on Competitive Advantage: A Mediation Role of Reputation and Customer Satisfaction. International Journal of Business and Management, 9(5), 109-124.

Erkmen, T., \& Esen, E. (2014). The Mediating Role of Trust to Managers on the Relationship between Corporate Reputation Practices and Employees' Course of Actions to Customers. Social Responsibility Journal, 10(2), 282-296.

Fauska, P., Kryvinska, N., \& Strauss, C. (2013). The role of e-commerce in B2B markets of goods and services. International Journal of Services, Economics, and Management, 5(1-2), 41-71. 
Eisenhardt, K.M. \& Martin, J.A. (2000). Dynamic Capability: What Are They? Strategic Management Journal, 21(1), 1105-1121.

Gao, T., \& Tian, Y. (2014). Mechanism of Supply Chain Coordination based on Dynamic Capability Framework-the mediating Role of Manufacturing Capabilities. Journal of Industrial Engineering and Management, 7(5), 1250-1267.

Gaurangkumar, B. (2015). Cost Benefit Analysis of Corporate Social Responsibility (CSR). Journal of Advances in Management, 8(5), 7-12.

Gazzola, P. (2014). Corporate Social Responsibility and Companies' Reputation. Network Intelligence Studies, 2(1/3), 74-84.

Golgeli, K. (2014). Corporate Reputation Management: The Sample of Erciyes University. Procedia - Social and Behavioral Sciences, 122, 312-318.

Hair, J., Black, W.C., Babin, B.J., \& Anderson, R.E. (2010). Multivariate Analysis, 7th edition. NJ: Pearson Education International.

Helfat, C., Finkelstein, S., Mitchell, W., Peteraf, M.A., Singh, H. \& Teece, D. (2007). Dynamic Capability: Understanding Strategic Change in Organizations. MA: Blackwell.

Helfat, C.E., \& Winter, S.G. (2011). Untangling Dynamic and Operational Capabilities: Strategy for the Never-Changing World. Strategic Management Journal, 32(11), 12431250.

Hongjun, X. (2014). Will Institutional Distance Affect Multinational Firms' CSR Performance in a Host Country? Journal of China Economist, 9(5), 108-122.

Hou, J. (2008). Toward a Research Model of Market Orientation and Dynamic Capabilities. Journal of Social Behavior and Personality, 36(9), 1251-1268.

Kaur, P. (2015). Corporate Social Responsibility: Present Scenario in India. Journal of Commerce \& Management Thought, 6(3), 496-511.

Kaveh, D., Bamipour, E.M., \& Far, M.S. (2015). The Relationship between Knowledge Management and Competitive Advantage: A Case Study in Small and Medium-Sized Companies in the Packaging Industry of Khorasan Razavi. European Online Journal of Natural and Social Sciences, 4(1), 650-659.

Kylaheiko, K. \& Sandstrom, J. (2007). Strategic Options-based Framework for Management of Dynamic Capabilities in Manufacturing Firms. Journal of Manufacturing Technology Management, 18(8), 966-984.

Ling, L.S., Tee, O.P., \& Eze, U.C. (2014). Conceptualizing Knowledge Management and Information Infrastructure Capability for Competitive Advantage: A Malaysian Perspective. Journal of Global Information Technology Management, 17, 117-138. 
Marichova, A. (2014). The dynamic capabilities of the firm - a major factor for sustainable competitive advantage: A study of Bulgarian construction industry. Ovidius University Annals Series: Civil Engineering, 16, 53-64.

Mark, D., Groza, M.D., Pronschinske, M.R., \& Walker, M. (2011). Perceived Organizational Motives and Consumer Responses to Proactive and Reactive CSR. Journal of Business Ethics, 102, 639-652.

Martínez, P., \& del-Bosque, I.R. (2014). Sustainability Dimensions: A Source to Enhance Corporate Reputation. Corporate Reputation Review, 17(4), 239-253.

Masteika, I., \& Cepinskis, J. (2015). Dynamic Capabilities in Supply Chain Management. Procedia-Social and Behavioral Sciences, 213, 830-835.

N'Da, K., Bergeron, F., \& Raymond, L. (2008). Achieving advantages from business to business electronic commerce: An empirical validation of an integrative framework. International Journal of Electronic Business, 6(5), 516-549.

Olmedo-Cifuentes, I., Mart1'nez-Leo'n, I.M., \& Davies, G. (2014). Managing Internal Stakeholders' Views of Corporate Reputation. Journal of Service Business, 8, 83-111.

Pavlou, P.A., \& El-Sawy, O.A. (2011). Understanding the Elusive Black Box of Dynamic Capabilities. Journal of Decision Sciences, 42(1), 239-273.

Roger, B.J. (2010). Market-Based Management: Strategies for Growing Customer Value and Profitability. New Jersey: Prentice Hall.

Sakas, D., Vlachos, D., \& Nasiopoulos. (2014). Modelling strategic management for the development of competitive advantage, based on technology. Journal of Systems and Information Technology, 16(3), 187-209.

Saloner, G., Andrea, S., \& Joel, P. (2001). Strategic Management. New York: John Wiley \& Sons.

Sandu, M.C. (2015). Reputation - An Important Element for Automotive Industry Profit? Procedia Economics and Finance, 32, 1035-1041.

Sharp, Z., \& Zaidman, N. (2010). Strategization of CSR. Journal of Business Ethics, 93, 5171.

Sontaite-Petkeviciene, M. (2014). Crisis management to avoid damage for corporate reputation: the case of retail chain crisis in the Baltic countries. Procedia-Social and Behavioral Sciences, 156, 452 - 457.

Teece, D.J. (2007). Explicating Dynamic Capabilities: The Nature and Micro foundations of (Sustainable) Enterprise Performance. Strategic Management Journal, 28(13), 13191350. 
Teece, D.J., Pisano, G., \& Shuen, A. (1997). Dynamic Capabilities and Strategic Management. Strategic Management Journal, 18(7), 509-533.

Tseng, S., \& Lee, P. (2014). The Effect of Knowledge Management Capability and Dynamic Capability on Organizational Performance. Journal of Enterprise Information Management, 27(2), 158-179.

Wang, C.L., \& Ahmed, P. K. (2007). Dynamic Capabilities: A Review and Research Agenda. International Journal of Management Reviews, 9(1), 31-51.

Wang, H. (2014). Theories for Competitive Advantage. In H. Hasan (Eds.), Being Practical with Theory: A Window in Business Research (1st ed., pp. 33-43). Australia: Theory Research Group.

Zheng, S., Zhang, W., Wu, X., \& Du, J. (2011). Knowledge-based dynamic capabilities and innovation in networked environments. Journal of Knowledge Management, 15(6), 1035-1051. 